\title{
ЛІНГВОДИДАКТИКА
}

УДК 811.161.2:81’34

О. Ю. Плахотнікова

\section{МЕТОДИКА СТВОРЕННЯ УЧНІВСЬКОГО ПІДКОРПУСУ УКРАЇНСЬКОГО ТРАНСКРИБОВАНОГО УСНОГО МОВЛЕННЯ}

У статті йдеться про особливості методики створення Учнівського підкорпусу українського транскрибованого усного мовлення в межах Корпусу українського транскрибованого усного мовлення. Цей Підкорпус містить мовлення іноземних студентів, що вивчають украйнську мову в Київському начіональному університеті імені Тараса Шевченка. Акцентовано увагу на особливостях добору матеріалу для иього ресурсу та продемонстровано інтерфейс анотаційного файлу в програмі ELAN. Для створення Підкорпусу використано авторську методику укладання Корпусу українського транскрибованого усного мовлення, описану в дисертаційному дослідженні.

Ключові слова: украйнська мова як іноземна, українське мовлення, корпусна тінгвістика, корпус усного мовлення, комп'ютерна програма ELAN, анотація, учнівський корпус, Корпус украӥнського транскрибованого усного мовлення.

Plakhotnikova O. The Methodology of Creating the Learner Subcorpus of Ukrainian Transcribed Speech. The article deals with methodological peculiarities of creating The Learner Subcorpus of Ukrainian Transcribed Speech (LSUTS) within The Corpus of the Transcribed Ukrainian Speech (CTUS). The topicality of the study is determined by the fact that Ukrainian speech of foreign students has not been studied yet, and the upcoming Learner Subcorpus contains the necessary audio- and videorecordings of reading and spontaneous speech, and enables such studies. The aim of the study is to develop theoretical and methodological basis for creating the LSUTS. The objectives of this article are: to propose methodological basis for constructing the LSUTS taking into account the main scientific achievements in the field of corpus linguistics; to characterize the peculiarities of selecting audio- and videorecordings for the above-mentioned resource. The developement of LSUTS has several stages of project implementation: at first, we developed the theoretical background for creating a model of the CTUS (general corpus, elaborated in our Ph.D. thesis); on this basis the prototype of the subcorpus was formed. We use the term "prototype" to denote the member of a category that best represents the category as a whole. Thus, LSUTS prototype is a working LSUTS model created for demonstration purposes, 
as well as part of the development process. We found out that the process of annotating videorecordings in ELAN computer program requires the use of converted audiorecordings in *wav format, and more accurate analysis of the soundwave. Consequently, we can make a conclusion that creation of the LSUTS within the CTUS meets the need of analysing the peculiarities of Ukrainian language acquisition by foreign students, and, accordingly, the use of this resource in teaching Ukrainian as a foreign language.

Key words: Ukrainian as a foreign language, Ukrainian speech, corpus linguistics, speech corpus, ELAN computer program, annotation, learner subcorpus, Corpus of the Transcribed Ukrainian Speech.

\section{Вступ}

Сьогодні корпусний метод активно використовують у сучасних лінгвістичних дослідженнях різних мов світу, адже він сприяє розширенню наукового пошуку й аналізу значного за обсягом мовного матеріалу, а також відкриває нові перспективи для застосування корпусів текстів у процесі вивчення та викладання мови. У зв'язку зі змінами в системі освіти України в контексті сучасних європейських та світових тенденцій методика викладання української мови як іноземної потребує залучення корпусів мовлення студентів для з'ясування рівня засвоєння мови, фіксації найчастотніших помилок залежно від рідної мови, а також розроблення стратегій викладання тощо.

Актуальність проблематики статті зумовлена недостатнім рівнем дослідження усного мовлення іноземних студентів, які вивчають українську мову; аудіо- та відеоматеріали читаного й спонтанного мовлення, що входять до корпусу усного мовлення, відкривають широкі можливості для аналізу мовлення й застосування цих даних у методиці викладання української мови як іноземної.

Електронні корпуси текстів, які найчастіше використовують у методиці навчання іноземної мови, називають “учнівськими корпусами”. Термін “учнівський корпус" є перекладом англійського терміна "learner corpus" та означає корпус, що містить мовні дані осіб, які вивчають цю мову як іноземну, незалежно від їхнього віку (Бук, 2007: 20). Учнівський корпус дає можливість досліднику аналізувати особливості засвоєння студентом іноземної мови ("second language acquisition”), i, відповідно, застосовувати цю інформацію у викладанні мови як іноземної. Учнівські корпуси, як зазначає С. Бук, дають змогу простежити різницю в засвоєнні рідної та іноземної мов, універсальні процеси в засвоєнні іноземної мови, роль рідної мови у вивченні 
іноземної, фіксувати та класифікувати найчастотніші помилки залежно від рідної мови учня (а також рівня володіння іноземною мовою, освіти та ін.), виявити мовну варіативність, індивідуальні особливості мовлення, розробити стратегії навчання тощо (Бук, 2007: 20-21).

Проблемам створення та використання учнівських корпусів у методиці викладання іноземних мов присвячено такі зарубіжні лінгвістичні праці, як-от: С. Гранжер (2008), А. Камараулі, М. Камараулі та 3. Пуртсхвадзе (2014); в українському мовознавстві ці аспекти досліджено в статтях С. Бук (2007), А. Пампурак (2012), Л. Коцюк (2014) тощо. Спробами створення учнівських корпусів в Україні $€$ Ukrainian Corpus of Learner English (Київський національний лінгвістичний університет) та Ostroh Academy Corpus of Learner English (Національний університет «Острозька академія») (Kotsyuk, 2014: 10).

Учнівські корпуси є порівняно новим видом корпусів текстів, адже з'явилися вони наприкінці 1980-х / на початку 1990-х pp. (Granger, 2008: 259). Відтоді було створено чимало різноманітних ресурсів для різних мов світу: The FALKO (2004), The Louvain International Database of Spoken English Interlanguage (2010), Leiden Learner Corpus (2015), The International Corpus of Learner English (2020) тощо. Найбільше учнівських корпусів текстів створено в Бельгії, Великобританії, Китаї, Німеччині (Kotsyuk, 2014: 10). Існує також Асоціація учнівських корпусів (Learner Corpus Association), яка, зокрема, сприяє формуванню подібних ресурсів для різних мов світу, проведенню досліджень у цій галузі; ця організація має свій вебсайт та раз на два роки проводить конференції (Learner Corpus Research Conferences). На вебсайті розміщено актуальний список уже розроблених учнівських корпусів з усього світу (190 позицій).

Прикметно, що на сьогодні у світі учнівських корпусів писемних текстів існує значно більше, аніж учнівських корпусів усного мовлення; це зумовлено тим, що процеси добору записів і транскрибування усного мовлення надзвичайно складні й вимагають багато зусиль і часу, особливо в разі створення мультимедійних корпусів (із залученням аудіо- та відеоматеріалів). Саме тому вбачаємо необхідність у створенні мультимедійного Учнівського підкорпусу українського транскрибованого усного мовлення (далі - УПУТУМ), що містить аудіо- та відеозаписи усного мовлення іноземних студентів, які вивчають українську мову. 
Мета цієї розвідки - розробити теоретичні та методологічні засади створення УПУТУМ. Завдання статті - запропонувати методологічні засади створення УПУТУМ з урахуванням основних досягнень учених у галузі корпусної лінгвістики; схарактеризувати особливості добору аудіо- та відеозаписів для цього ресурсу.

\section{Методи дослідження}

Для розв’язання поставлених у роботі завдань і досягнення основної мети дослідження застосовано загальнонаукові та спеціальні методи. На основі описового методу й методу узагальнення здійснено огляд стану проблеми та спостереження над фактичним матеріалом. Метод моделювання слугував для створення теоретичних засад формування моделі УПУТУМ та побудови цього ресурсу. У роботі також застосовано спеціальні методи, серед яких - експериментально-фонетичний: аудитивний аналіз використано для початкової інтерпретації фонетичного матеріалу дослідження; для підтвердження результатів аудитивного аналізу й проведення процедури фонетичного транскрибування мовлення дикторів слугував метод акустичного аналізу. Аудитивний та акустичний аналіз мовленнєвого сигналу здійснено за допомогою комп’ютерних програм ELAN i Praat.

\section{Виклад основного матеріалу}

Будь-який корпус усного мовлення формують із конкретною метою і з урахуванням специфіки наукових розробок та прикладних систем, для яких буде використано цей масив даних. У процесі побудови проєкту будь-якого корпусу текстів важливими етапами процесу є початковий - створення корпусу текстів та аналіз способів його подальшого застосування в наукових дослідженнях; основоположними $є$ питання структури й змістового наповнення корпусу текстів, що становлять підгрунтя концепції електронних текстових корпусів.

Проєктування УПУТУМ має кілька ступенів реалізації: спочатку було напрацьовано теоретичні засади створення моделі Корпусу українського транскрибованого усного мовлення (далі - КУТУМ, генерального корпусу, розробленого в нашому дисертаційному дослідженні) (Плахотнікова, 2017b); на їх основі було сформовано прототип УПУТУМ, що після вдосконалення стане повноцінним підкорпусом усного мовлення іноземних студентів. Під прототипом маємо на увазі частину категорії, що найкращим чином представляє цю конкретну 
категорію в цілому. Відповідно, прототип має всі властивості, притаманні зазначеній категоріі. У галузі розроблення програмного забезпечення прототип - це робоча модель продукту, розроблена з метою демонстрації і тестування ії можливостей; саме це визначення найповніше відображає сутність прототипу корпусу (Prototype). Отже, прототип УПУТУМ є проміжним етапом проектування Підкорпусу й допомагає з'ясувати основні технічні можливості цього ресурсу.

Оскільки прототип УПУТУМ є частиною КУТУМ, розробленого О. Плахотніковою на базі навчальної лабораторії експериментальної фонетики Інституту філології Київського національного університету імені Тараса Шевченка, варто зазначити, що цей Корпус є фонетично анотованим і містить індивідуалізовані транскрипційні записи аудіотекстів, адаптовані до комп'ютерної програми ELAN, на базі якої розроблено анотаційні файли аудіозаписів. Частина матеріалів Корпусу представлена на сайті The Language Archive Інституту психолінгвістики імені Макса Планка (м. Неймеген, Нідерланди) (Plakhotnikova).

Побудова УПУТУМ передбачає виконання таких етапів дослідження:

1. На початковому етапі необхідно було провести підготовку експериментального матеріалу дослідження.

Джерелом мовленнєвого матеріалу для акустичної бази даних було дібрано відео- та аудіозаписи читаного й спонтанного мовлення; плануємо постійно доповнювати базу даних новими аудіо- та відеозаписами. На сьогодні матеріалом прототипу УПУТУМ слугують фрагменти усних текстів загальною тривалістю 219 хвилин 57 сек. це аудіозаписи мовлення студентів-іноземців 1 та 2 курсів освітньої програми «Медицина» ННЦ «Інститут біології та медицини» Київського національного університету імені Тараса Шевченка (всі ці аудіотексти представляють читане мовлення), а також фрагменти 21 відеозапису загальною тривалістю 128 хвилин 50 сек. мовлення студентів 1 курсу освітньої програми «Медицина» (ці відеоматеріали містять спонтанне непідготовлене мовлення). Усі відео- та аудіозаписи були здійснені в межах викладання курсу української мови за професійним спрямуванням у 2020 році. Для записів читаного мовлення дібрано українські скоромовки, а також тематичні тексти українською мовою (включно з авторськими текстами студентів).

Щоб текстове наповнення Підкорпусу було збалансованим, добір дикторів здійснено за кількома критеріями: 
1) за освітою і фахом: усі диктори є студентами медичного факультету університету, мають повну середню освіту;

2) за статтю: 24 диктори жіночої статі та 25 дикторів чоловічої (загальна кількість дикторів - 49);

3) за віком: усі диктори, окрім одного (віком 31 рік), належать до однієї вікової групи - 18-25 р.;

4) за рідною мовою: усі диктори походять з різних країн (Єгипту, Ємену, Індії, Ірану, Йорданії, Камеруну, Лівану, Нігерії, Туреччини) та $є$ носіями різних мов, як-от: 8 дикторів - носії арабської мови (з Єгипту, Ємену, Йорданії та Лівану); 8 дикторів - носії перської мови (Іран); 12 дикторів - носії мови малаялам (Індія), 11 дикторів - носії мови гінді (Індія); 3 диктори - носії мови каннада (Індія); 5 дикторів носії турецької мови (3 диктори з Туреччини та 2 білінгви з Ірану); 1 диктор - носій мови телугу (Індія); 1 диктор - носій мови маратхі (Індія); 1 диктор - носій французької мови (Камерун); 1 диктор - носій англійської мови (Нігерія). Комп’ютерна програма ELAN дає змогу анотувати відеозаписи; у кожному анотаційному файлі зазначаємо дані про диктора (вік, стать, рідна мова, рівень володіння іноземною мовою / рік ії̈ вивчення).

Табл. 1

Інформація про матеріали УПУТУМ

\begin{tabular}{|c|c|c|c|}
\hline $\begin{array}{c}\text { Країна } \\
\text { походження }\end{array}$ & $\begin{array}{l}\text { Загальна } \\
\text { кількість } \\
\text { дикторів }\end{array}$ & Рідна мова & $\begin{array}{l}\text { Загальна кількість і тип } \\
\text { аналізованого матеріалу }\end{array}$ \\
\hline Єгипет & 5 & арабська & 9 аудіозаписів, 2 відеозаписи \\
\hline Ємен & 1 & арабська & 1 відеозапис, 1 аудіозапис \\
\hline \multirow{5}{*}{ Індія } & \multirow{5}{*}{28} & гінді (11) & \multirow{5}{*}{$\begin{array}{l}12 \text { відеозаписів, } \\
129 \text { аудіозаписів }\end{array}$} \\
\hline & & малаялам (12) & \\
\hline & & каннада (3) & \\
\hline & & телугу (1) & \\
\hline & & маратхі (1) & \\
\hline Іран & 8 & перська & 22 аудіозаписи, 4 відеозаписи \\
\hline Йорданія & 1 & арабська & 1 аудіозапис \\
\hline Камерун & 1 & французька & 6 аудіозаписів, 1 відеозапис \\
\hline Ліван & 1 & арабська & 2 аудіозаписи \\
\hline Нігерія & 1 & англійська & 6 аудіозаписів, 1 відеозапис \\
\hline Туреччина & 3 & турецька & 11 аудіозаписів \\
\hline
\end{tabular}


2. Наступний етап роботи над прототипом УПУТУМ передбачав створення архіву аудіо- та відеозаписів з асоційованою анотацією. Для цього спочатку сформовано базу й відредаговано електронні версії прочитаних текстів. База електронних текстів, що співвідноситься з відповідними аудіо- та відеозаписами, необхідна для зручності опрацювання масиву даних та створення анотацій з орфографічними записами.

3. Потім було проведено опрацювання аудіо- та відеофайлів. Усі аудіозаписи конвертовано в некомпресований формат *.wav, оскільки він дає змогу зберегти високу якість мовленнєвого сигналу, а також це один з небагатьох форматів медіафайлів, що розпізнається в програмі ELAN. Що ж до відеозаписів, то варто зауважити, що генеральний корпус КУТУМ не містив жодного анотованого відеозапису, тому на цьому та наступному етапах було протестовано можливості роботи з відеофайлами у програмі ELAN. Усі відеофайли збережені у форматі *.mp4, який розпізнається в програмі ELAN; для кожного відеозапису створено асоційований аудіофайл шляхом конвертування відеофайлу в некомпресований формат *.wav (це необхідна умова анотування відеофайлів у програмі ELAN, потрібно завантажувати як відео-, так й аудіофайл). На цьому самому етапі здійснено метаопис звукозаписів корпусу, що об'єднував як змістові елементи даних (відомості про диктора та текст), так і формальні (номер аудіозапису, прізвище автора анотації, розширення файлу); ця інформація була введена вручну (Плахотнікова, 2017а: 146).

4. Першочерговим завданням наступного етапу побудови прототипу УПУТУМ $є$ анотування всіх аудіо- та відеофайлів у комп'ютерній програмі ELAN (створення анотаційних файлів у форматі *.eaf), що розширить можливості фонетичного аналізу українського мовлення іноземних студентів. Усі відео- та звукозаписи ресурсу було розміщено в одній директорії, що й становить прототип УПУТУМ (кожному запису має відповідати анотаційний файл із відповідною назвою); це також зумовлено умовами роботи комп'ютерної програми ELAN, оскільки без аудіо- чи відеофайлу, що знаходиться в одній папці з анотаційним файлом *.eaf, перегляд анотаційного файлу неможливий (не буде мовленнєвого сигналу) (Плахотнікова, 2017a: 146).

Важливим етапом створення анотаційного файлу *.eaf у програмі ELAN $є$ сегментування аудіотекстів на синтагми. Термін “синтагма" 
використовуємо на позначення мінімального структурно-смислового компонента мовленнєвого потоку (як читаного, так і спонтанного мовлення), який складається з одного або більше слів, пов'язаних структурою й за смислом, і характеризується типовістю інтонаційного контуру. При цьому основним критерієм визначення меж синтагми постає пауза (Плахотнікова, 2017b: 114).

Аналіз звукової хвилі в програмах Praat i ELAN дає змогу розв'язати проблему поділу мовленнєвого сигналу на синтагми. Паузи (заповнені і незаповнені) є підставою для проведення сегментації на акустичні фрагменти. Після сегментації вручну виконуємо лінгвістичне анотування аудіотекстів прототипу УПУТУМ із використанням транскрипційних записів за допомогою кириличної й латинської графіки, розроблених у нашому дисертаційному дослідженні (Плахотнікова, 2017b). Зауважимо, що для коректного транскрибування в програмі ELAN мовленнєвий сигнал обов'язково треба спочатку детально проаналізувати на осцилограмі в програмі Praat.

На рис. 1 представлено інтерфейс чотирирівневої анотації запису диктора АП у прототипі УПУТУМ. Рівень анотації «Orthography» містить орфографічний запис тексту; рівень анотації «Transcription» відображає індивідуалізований транскрипційний запис аудіотексту за допомогою кириличної графіки, а «Transcription IPA» - за допомогою латинської графіки (засобами Міжнародного фонетичного алфавіту); рівень анотації «Translation_EN» містить переклад тексту англійською мовою, необхідний для забезпечення можливості використання КУТУМ широким колом користувачів, що не володіють українською мовою.

\section{Висновки}

У статті запропоновано методологічні засади побудови Учнівського підкорпусу українського транскрибованого усного мовлення (УПУТУМ) у межах Корпусу українського транскрибованого усного мовлення (КУТУМ), який водночас зумовив потребу дослідження особливостей засвоєння іноземними студентами української мови. Запропонована методика $є$ універсальною і може бути використана для побудови подібного ресурсу для будь-якої мови, незалежно від специфіки ії фонетичної будови. Отже, створення УПУТУМ 


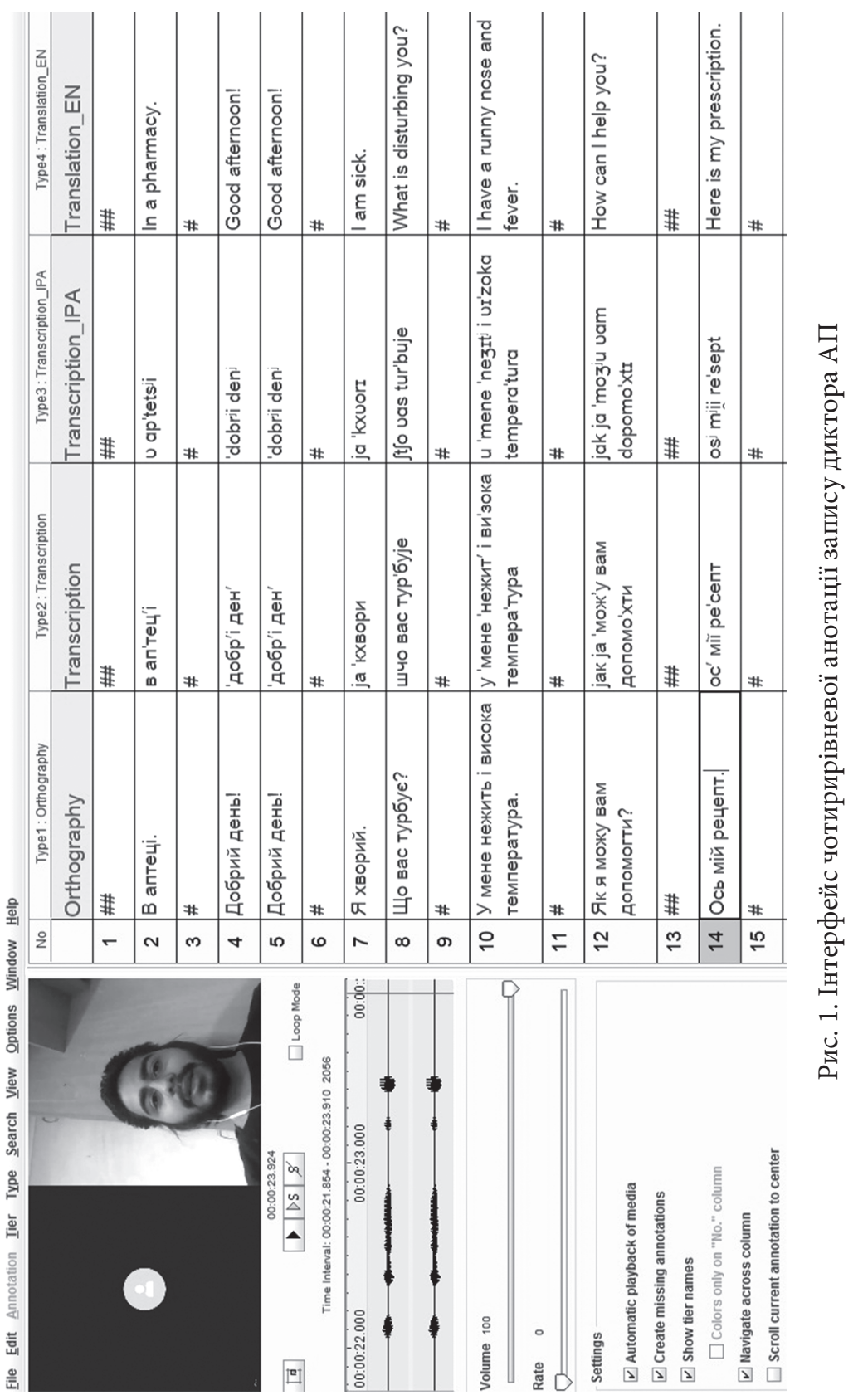


уможливлює застосування цього ресурсу у викладанні курсу української мови як іноземної.

Перспективою досліджень $є$ аналіз усного мовлення дикторів Підкорпусу на базі анотаційних файлів, що містять індивідуалізовані транскрипційні записи.

\section{ЛІТЕРАТУРА}

1. Бук, С. (2007). Учнівські корпуси в методиці викладання іноземної мови. Теорія і практика викладання української мови як іноземної, 2, 19-23. 2. Камараулі, А., Камараулі, M., \& Пуртсхвадзе, 3. (2014). Learner Corpora (навчальні корпуси) та їх потенціал для мультилінгвальної освіти. Міжнародний журнал у галузі мультилінгвальної освіти, 3, 79-91. 3. Пампурак, А. (2012). Застосування учнівських корпусів текстів при навчанні лексики іноземної мови. Студентські наукові записки. Серія «Філологічна», 5, 144-146. 4. Плахотнікова, О. Ю. (2017). Корпус українського транскрибованого усного мовлення: засади створення. Наук. вісн. Дрогоб. держ. пед. ун-ту імені Івана Франка. Серія «Філологічні науки. Мовознавство», 7, 145-148. 5. Плахотнікова, О. Ю. (2017). Корпус українського усного мовлення: теоретичні засади побудови й основи практичного втілення. (Дис. ... канд. філол. наук). Київ: КНУ імені Тараса Шевченка. 6. Granger, S. (2008). Learner corpora. In Corpus Linguistics. An International Handbook. (Vol. 1.). (pp. 259-275). Berlin \& New York: Walter de Gruyter. 7. Kotsyuk, L. M. (2014). Learner corpora as a feedback on curriculum. Наук. зап. Наи. унmy «Острозька академія». Серія «Філологічна», 46, 10-13. 8. Plakhotnikova, O. Corpus of the Transcribed Ukrainian Speech. The Language Archive. MPI Nijmegen. Узято з https:// archive.mpi.nl/tla/islandora/object/tla\%3A1839_00_1390CD7C_579F_45F7_9B00_65A31 FC980DF. 9. Prototype. Glossary of Linguistic Terms. Узято з http://www.glossary.sil.org/ term/prototype.

\section{REFERENCES}

1. Buk, S. (2007). Uchnivski korpusy v metodytsi vykladannia inozemnoi movy [Learner corpora in the techniques of teaching a foreign language]. Teoriia i praktyka vykladannia ukrainskoi movy yak inozemnoi - Theory and practice of teaching Ukrainian as a foreign language, 2, 19-23 [in Ukrainian]. 2. Kamarauli, A., Kamarauli, M., \& Purtskhvadze, Z. (2014). Learner Corpora (navchalni korpusy) ta yikh potentsial dlia multylinhvalnoi osvity [Learner Corpora and their potential for multilingual education]. Mizhnarodnyi zhurnal $u$ haluzi multylinhvalnoi osvity - International Journal of Multilingual Education, 3, 79-91 [in Ukrainian]. 3. Pampurak; A. (2012). Zastosuvannia uchnivskykh korpusiv tekstiv pry navchanni leksyky inozemnoi movy [The use of learner text corpora in teaching vocabulary of a foreign language]. Studentski naukovi zapysky. Seriia «Filolohichna»-Student scientific notes. Philological Series, 5, 144-146 [in Ukrainian]. 4. Plakhotnikova, O. Yu. (2017). Korpus ukrainskoho transkrybovanoho usnoho movlennia: zasady stvorennia [The Corpus of Transcribed Ukrainian Speech: principles of construction]. Nauk. visn. Drohob. derzh. ped. un-tu imeni Ivana Franka. Seriia «Filolohichni nauky. Movoznavstvo»-Scientific Bulletin of Drohobych State Pedagogical University named after Ivan Franko. Series «Philological Sciences. Linguistics», 7, 145-148 [in Ukrainian]. 5. Plakhotnikova, O. Yu. (2017). Korpus 
ukrainskoho usnoho movlennia: teoretychni zasady pobudovy y osnovy praktychnoho vtilennia [Ukrainian speech corpus: the theoretical basis of construction and practical implementation]. Candidate's thesis. Kyiv: KNU imeni Tarasa Shevchenka [in Ukrainian]. 6. Granger, S. (2008). Learner corpora. In Corpus Linguistics. An International Handbook. (Vol. 1). (pp. 259-275). Berlin \& New York: Walter de Gruyter [in English]. 7. Kotsyuk, L. M. (2014). Learner corpora as a feedback on curriculum. Nauk. zap. Nats. un-tu "Ostrozka akademiia». Seriia "Filolohichna» - Scientific notes of the National University "Ostroh Academy». Philological Series, 46, 10-13 [in English]. 8. Plakhotnikova, O. Corpus of the Transcribed Ukrainian Speech. The Language Archive. MPI Nijmegen. Retrieved from https:// archive.mpi.nl/tla/islandora/object/tla\%3A1839_00_1390CD7C_579F_45F7_9B00_65A31 FC980DF [in English]. 9. Prototype. Glossary of Linguistic Terms. Retrieved from http:// www.glossary.sil.org/term/prototype [in English].

Плахотнікова Олена Юріївна - кандидат філологічних наук, асистент кафедри мовної підготовки, Навчально-науковий центр «Інститут біології та медицини», Киівський національний університет імені Тараса Шевченка; проспект Академіка Глушкова, 2, Київ, 03127, Україна.

Tel.: +38-099-629-29-72

E-mail: olenaplahotnikova@gmail.com

https://orcid.org/0000-0003-4274-8554

Plakhotnikova Olena Yuriivna - Candidate of Philological Sciences (Ph.D.), Assistant Professor at the Department of Language Training, Educational and Scientific Center «Institute of Biology and Medicine», Kyiv National Taras Shevchenko University; 2 Akademika Hlushkova Avenue, Kyiv, 03127, Ukraine.

Надійшла до редакції 23 серпня 2021 року

\section{CITATION}

ДСТУ 8302:2015: Плахотнікова О. Ю. Методика створення учнівського підкорпусу українського транскрибованого усного мовлення. Лінгвістичні дослідження: зб. наук. пр. Харк. нац. пед. ун-ту імені Г. С. Сковороди. Харків, 2021. Вип. 55. С. 164-174. DOI: https://doi.org/10.34142/23127546.2021.55.15

AРА: Плахотнікова, О. Ю. (2021). Методика створення учнівського підкорпусу українського транскрибованого усного мовлення. Лінгвістичні дослідження, 55, 164174. DOI: https://doi.org/10.34142/23127546.2021.55.15 